\title{
Florida Growth Management: Public Participation and the Plan Amendment Process ${ }^{1}$
}

Roy Carriker ${ }^{2}$

\section{Introduction}

Counties and municipalities in Florida are required by Florida's Growth Management Act of 1985 to develop, adopt, and implement comprehensive plans (see EDIS documents FE642, Comprehensive Planning for Growth Management in Florida, and FE643, Florida's Growth Management Act: An Introduction and Overview). The Florida legislature intended that local comprehensive plans be living documents--capable of adjusting appropriately to address changing growth management issues confronting local communities over time. Accordingly, the Growth Management Act provides a process by which local governments can amend their comprehensive plans. The Florida legislature also intended that residents of a community where development is taking place be enabled and encouraged to participate at all levels of the comprehensive planning and land development process. This publication outlines specific steps in the process for considering proposed amendments to the local comprehensive plan, identifying each juncture in the process where a member of the public can make input.

\section{Amending Local Government Comprehensive Plans}

Comprehensive plans can be amended, typically because:

- A land owner desires to develop in a manner inconsistent with the local comprehensive plan.

- The Evaluation and Appraisal Report (EAR) has generated a need for an amendment.

- The legislature has imposed a new planning requirement on local governments, resulting in the need for a plan amendment.

\section{Public Hearings and the Plan Amendment Process: Affected Persons and Standing}

- The plan amendment process includes specific junctures where public hearings must be held.

- While anyone may speak at public hearings or submit written comments related to a proposed comprehensive plan amendment, only an "affected person" has "standing to challenge" a

1. This is EDIS document FE645, a publication of the Food and Resource Economics Department, Florida Cooperative Extension Service, Institute of Food and Agricultural Sciences, University of Florida, Gainesville, FL. Published August 2006. Please visit the EDIS website at http://edis.ifas.ufl.edu.

2. Roy Carriker, Professor, Food and Resource Economics Department, Florida Cooperative Extension Service, Institute of Food and Agricultural Sciences, University of Florida, Gainesville, FL.

The Institute of Food and Agricultural Sciences (IFAS) is an Equal Opportunity Institution authorized to provide research, educational information and other services only to individuals and institutions that function with non-discrimination with respect to race, creed, color, religion, age, disability, sex, sexual orientation, marital status, national origin, political opinions or affiliations. U.S. Department of Agriculture, Cooperative Extension Service, University of Florida, IFAS, Florida A. \& M. University Cooperative Extension Program, and Boards of County Commissioners Cooperating. Larry Arrington, Dean 
local comprehensive plan amendment at a later date.

- An affected person under Florida law includes:

1. One who owns property, resides, or owns or operates a business within the boundaries of the local government that adopted the plan or plan amendment.

2. In the case of future land-use map amendments, one who owns property outside the local government jurisdiction, and which property abuts the property affected by the future land use map amendment.

3. The local government that adopted the plan or plan amendment.

4. An adjoining local government that can demonstrate substantial impacts.

- To have their views considered, and to establish standing to challenge later actions, an affected person must submit oral or written comments, recommendations, or objections to the local government during the period of time beginning with the transmittal hearing and ending with the adoption of the plan or plan amendment.

Standing can be established by:

1. Presentations at the hearings.

2. Letters sent to elected officials at or between the transmittal hearing and final adoption of the plan amendment.

\section{Small-scale Versus Large-scale Plan Amendments}

Florida law draws a distinction between small-scale amendments and large-scale amendments. The amendment process differs between the two, as do the opportunities for public participation.

\section{Small-scale Amendments}

- Relate to a parcel of ten acres or less.
- Do not involve a text change to the local comprehensive plan or amendment to the future land-use map.

- May be made by local government at any time (with some limitations).

- Must include hearings before the Land Planning Agency.

- Require at least one publicly-noticed adoption hearing at which the public may comment.

- Do not undergo further review.

- Take effect within 31 days of adoption by the local government, unless challenged by an affected party.

- An "affected person" desiring to challenge a small-scale amendment must file a petition with the Division of Administrative Hearings within 30 days after its adoption by the local government.

\section{Large-scale Amendments}

- Relate to parcels larger than ten acres.

- Can be made only twice a year.

- Undergo greater review than do small-scale amendments.

- Typically involve at least three local public hearings.

- May involve local government workshops.

- Are subject to review and comment by the Florida Department of Community Affairs, which may also request changes through its Objections, Recommendations, and Comments (ORC) Report.

\section{Local Planning Agency Public Hearings}

- The local planning agency, after legal notice is given, holds a public hearing on proposed large-scale amendments. This affords an opportunity for members of the public to attend 
the hearing and provide spoken and/or written comments on the proposal.

- Sign-up Forms. The Department of Community Affairs (DCA) provides a sign-up form that all local governments are required to use.

- Citizens who attend a hearing should write their name, address, and phone number on the form or, if forms are unavailable, on a separate sheet of paper, and submit the information to the person in charge of keeping notes at the hearing.

- The completed sign-up form is submitted to DCA as part of the hearing record and serves as proof of participation in the hearing.

- Proof of participation may be required for a participant to have legal standing to challenge later actions.

- After the public hearing, the local planning agency makes its recommendation on the proposed amendment to the governing body.

\section{Local Government Transmittal Hearings}

- After the planning agency hearing, the governing body holds a publicly-noticed "transmittal hearing" on the amendment.

- If the governing body decides against the amendment, the issue dies.

- If the governing body approves the proposed large-scale amendment, the approved amendment is then sent to DCA and other state agencies for review.

- The transmittal hearing is an important opportunity for members of the public to attend the hearing, provide spoken and/or written comments, and help establish standing should they wish to challenge later actions.

\section{Department of Community Affairs Transmittal Review}

- DCA must review a proposed amendment when an affected person, a regional planning council, a commenting state agency, or the local government requests review.

- A request for DCA review must be made within 30 days after the local government transmits the complete amendment to DCA.

- If request for DCA review is not made within the 30-day window, DCA may choose not to review the amendment.

- Thus, any member of the public who wants DCA to review a proposed amendment must submit in writing the request, comments, and verification that he/she is an affected person within 30 days of the date DCA officially receives the amendment.

- DCA has 60 days from the time it receives the proposed amendment to undertake its review.

- Upon completing its review, DCA may either take no action, or issue an Objections, Recommendations, and Comments (ORC) report that is sent back to the local governing body. An ORC report identifies any problems with the amendment such as inconsistency with other portions of the comprehensive plan, or lack of appropriate data and analysis in support of the amendment.

\section{Local Government Adoption Hearing}

- If DCA issues an ORC, the local government must review the report and may possibly modify the amendment.

- If an ORC is not issued, the local government may proceed directly to the adoption hearing.

- The local government has 60 days to adopt or adopt with changes the large-scale amendment at the "adoption hearing." [However, if the amendment under consideration is an Evaluation and Appraisal Report (EAR) Amendment, the local government has 120 days to adopt or adopt with changes.] 
- The adoption hearing is the last opportunity for a member of the public to provide input or help establish standing.

- Even if a member of the public has previously established standing, speaking or submitting written comments at the adoption hearing may be desirable, as the content of the amendment may have changed from the transmittal hearing.

\section{DCA Adoption Review}

- If an ORC report has been issued, DCA must then review the amendment again to ensure it is consistent with the Growth Management Act and Rule 9J-5 of the Florida Administrative Code (which contains DCA's rules, regulations, and guidelines governing compliance with provisions of the Growth Management Act).

- The DCA Adoption Review applies only to issues raised in the ORC report and to any changes made to the plan by the amendment.

- At the end of its 45-day review period, DCA publishes a "Notice of Intent" to find the amendment either in compliance or not in compliance.

\section{Summary and Suggestions for Further Reading}

The 1985 Growth Management Act gives residents of communities where development is occurring the right to become involved at all levels of the local comprehensive planning and land development process should they choose to do so. This EDIS document has described the plan amendment process, identifying those junctures at which public participation may occur.

The success of Florida's growth management system depends upon the diligence and actions of citizens. They should:

- Read and understand the comprehensive plans that have been adopted by their local governments.

- Monitor the decisions of their local governments to make sure those decisions are consistent with the plan.
- Monitor proposed amendments to the plan.

If circumstances warrant, citizens can cooperate to challenge actions of government that violate the Growth Management Act. In an article entitled, "How Citizens Can Achieve Standing to Litigate: Citizen Enforcement of the Growth Management Act" the legal director of 1000 Friends of Florida provides a brief review of the process for citizen challenges and some general advice on how best to proceed. The website of 1000 Friends of Florida (http://www.1000friendsofflorida.org) is a good source of information regarding comprehensive planning and land development regulation in Florida.

Another informative website is maintained by the Florida Department of Community Affairs at http://www.dca.state.fl.us. 